\title{
REFLECTION OF POLITICAL RESTRUCTURING ON URBAN SYMBOLS: THE CASE OF PRESIDENTIAL PALACE IN ANKARA, TURKEY
}

\author{
Ezgi ORHAN \\ Cankaya University, City and Regional Planning, Ankara, 06530 Turkey \\ E-mail: ezgiorhann@gmail.com
}

Received 09 September 2015; accepted 26 November 2015

\begin{abstract}
Ankara, capital of Turkey has been the revolution space of the country after the proclamation of republic in 1923 . The city has carried out the urban symbols of the republican ideology and modernity vision created by the nationalist administrators and elites. The newly established state used architecture and urban planning in transmitting the ideals of national unity and sovereignty by breaking off its ties from Ottoman heritage. After the span of eighty years, Turkey has experienced a new political hegemony. Post-2000s' political approach changed the urban symbols of early Republican period and redesigned the capital in line with its ideological basis. One of the most concrete transformations is observed in the presidential palace of the country which conveys the political intents of each period through its spatial and architectural organizations. This study, therefore, aims to put forward the change in urban symbols and their meanings by focusing on the presidential palace. The palaces are investigated in observational domains; their spatial configurations, buildings, and symbols in relation to the political intents on urban areas and public realm. This paper concludes that in both periods presidential palaces with respect to their spatial and architectural designs are regarded as the icons in representing the dominant political power; the former used it as an instrument of national sovereignty whereas the latter used it as a mark of dominancy over the nation.
\end{abstract}

Keywords: political restructuring, capital city, urban symbols, presidential palace, spatial organization, Ankara.

\section{Introduction}

The symbolic dimension of landscape is related to the construction of collective historical memories. For Hutton, collective memory is "an elaborate network of social mores, values and ideals that mark out the dimensions of our imaginations according to the attitudes of the social groups to which we relate" (1993 in Osborne 1998: 432). In this sense, the capacity to sustain the collective memory relies on power and the memory and forgetting are hegemonically produced and maintained. As argued by Halbwachs, "the past is social and memory is socially acquired" (1992 in Mitchell 2013). Belanger (2002) identifies the desires of political elites to earn symbolic capital by controlling the meanings through "political economy of urban collective memory". In line with the Foucauldian discourse, Mitchell notes that "the hegemony of memory is never complete, as memory remains multiple and mobile, with fragments that are not subsumable in a holistic logic" (2013: 450). Therefore, spatial iconographies inspire meanings "as they are imagined, constructed, and employed in processes" (Evered 2008).
Urban design of space, architecture of buildings in addition to monuments and ceremonies are the agencies of the symbolic space that enable to create a sense of shared identity and collective memory. Gordon and Osborne (2004: 620) claims that "one of the principal strategies of nationalising in overcoming internal difference and plural imaginations is to construct a cohesive collective memory and associate the state with a nationals symbolic space". As the spaces that shape public memory and collective identity changes, the urban collective memory associated with the space also changes.

Urban space is the milieu of reflecting the social, economic and politic order of society. Political power forms the spaces that scale the city, holds the traces of values embedded by different cultures in the city, and acquires social identity. Political spaces can serve for the political and social integration, "as the monumentality of public buildings, their invitation to identification" (Minkenberg 2014: 5).

Capital cities are the addresses of political authority and "play a significant role in representing the ideals of 
a nation, or at least the national government's interpretation of these aspirations and ideals" (Shatkin 2005: 577). The politico-administrative centres are "symbolic theatres for national ideology, a reflection of the larger national stance towards urbanism, a catalyst for national economic development, and at least historically, a bridge between local culture and the "imagined community" of the nation-state" (Campbell 2000: 1). Being the host of nation's history and future ideals, physical development of capital cities is shaped by political intents and, their physical form in turn affects the political action. In other words, while the political power designs urban space of capitals, the urban space designs politics.

The cityscape of capital cities addresses the central offices, administrative functions and the symbols that reflect the political authority. The symbols derived from the political intentions and expectations for future and history express the authority and the national identity. Minkenberg claims that "through its architecture and urban design, a capital provides constructed spaces which serve as instruments and offer a language of representation for the entire nation" (2014: 7). The urban design, architecture, and monuments, notes Cinar, are functioning for the state "to establish its power and authority in controlling and dictating the norms that guide daily public life" (2014: 228). By constructing a city, the state becomes the engineer of the national authority, the urban space, and the way of citizens in experiencing the city and the way of life.

In the opening sentence of the book "Architecture, power and national identity" Lawrance Vale (1992) writes that "political power takes many forms". As accepted by many scholars, architecture and spatial planning have been manipulated to transmit the political power to society. As an instrument of state propaganda, monumental structures and spaces have been used to embody the values of dominant ideologies, which do not necessarily have to do with size, but with intensity of expression (Curtis 1996: 514). Minkenberg states that "public architecture, official buildings and the urban design of official places can be can always be interpreted as ingredients of the establishment of political legitimacy" (2014:3) whether it is assumed that architecture and urban design reflects the underlying ideology of political regime or they contribute to the constituting political reality. In explaining the relationship between power and architecture, these two major approaches claim basically that public spaces and buildings are "the material expression of political power, its exercise, and its form" (Minkenberg 2014: 3).

Although cityscapes of capital cities are considerably stable (Wusten 2000), the capital of Turkey has been experiencing a change in terms of political, social and historical geography. In parallel to the change in the time and political regime, the symbols of Ankara have exercised a shift drastically. The central premise of this article is the historical processes and symbolic spaces of different politics which made a capital city. Capital cities, as argued by Therborn $(2006,2010,2015)$, are the manifestations of political power. As nodes of politics and economics, capital cities are the centres and the representatives of nations.

With continuous imperial decline in the 19th century, Ottoman effect on Balkan and Anatolian cities diminished. In those cities, several significant structures in forms of residential buildings, bazaars, religious complexes, mosques, and bridges were constructed for diverse ethno-cultural groups. Similar to the Ottoman style in architecture, the built environment was identical with narrow, irregular and inward-turning street layout. The wave of nationalism and consequences of World War-I determined the end of the Empire. The Independence War against the imperialist occupation redefined the national territory of Turkey. Mustafa Kemal, later Ataturk, the founder of Turkish Republic, deliberately chose Ankara as the site for the new capital in order to reduce the political influence of the Ottoman Empire, to avoid the invasion risks and enhance militaristic capacity, and to serve as a new pole for economic development of the nation. Therefore, the new nation and the state constructed its own symbols and collective identity.

The modern affects both communal life and the rise of a nation. The Turkish project of nation-building has incorporated the development of symbols for the regime, a collective memory for past, a common vision for future, and their concrete representatives. Therefore, along with these goals, in Anatolia, a national capital rises from the multi-ethnic empire, "expressing itself in urban forms, building patterns, architectural styles, monumental icons, and in naming" (Therborn 2006: 234).

As a part of the Kemalist modernity project, city planning approaches would become a model of inspiration and especially the urban plan of Ankara as the capital city would reflect the modern way of life encompassing all spheres of city life. The concept of public space was created by the Turkish modernization and nationalization process. New public spaces, squares and parks, boulevards and streets and their naming with commemorative glories, buildings and monuments constituted not only the landscape of the city, but also a synthesis of Republican ideals. Mediating for communication milieu, boulevards and streets were aimed at serving as an artery of circulation and a showpiece of 
elegance, shoppers, flaneurs, and of shops, restaurants, banks, ministries and parks. Moreover, the new regime asserted itself in cultural forms to solidify the national awakening. National museums, operas, and halls were accompanied the movement. As the new state did not have available governmental buildings from the imperial time and reject the use of such buildings, new ministerial buildings and military offices were gradually added and designed with respect to national symbols in order to correspond sovereignty.

Ankara, as the new capital of the state, is intended to be the symbolic locus not only with the physical environment but also all other structures and spaces that imposing the power of regime, dignity of the state, and modern public sphere. Ergut (1999: 112) notes that "an examination of the process of building a national capital, as in Turkey, could be particularly illuminating in understanding the significance of its architecture, and the built environment in general, in relation to the idea of nationalism and national identity". The early republican public buildings and spaces hence communicated visually with the citizens and performed as the new ritual spaces. The nation builders constructed the landscape of sovereignty with didactic monuments and memorials, public gardens, state architecture, and regulative plans. Thus, in building the capital, the presence of the Republican memorials in the townscape of Ankara was remarkable.

Rejecting the authority of Ottoman monarchy and the Islamic caliphate which was governed from the Palaces of Sultans as the place of administrative mechanisms having grand architectural and monumental designs, the chief objective of the new regime of Turkey was the construction of a capital by grounding it with national imagination. Thus, the administrative functions were separated from each other and the house of presidency was distinguished from those units. In Ankara, the governmental district was designed along the new development axis of the city, the parliament building was placed at the southern part of the district and the presidential palace was planned to be annexed to the governmental core at the end of the axis to represent the power of national sovereignty.

The presidential palace is the spatial representative of connection of public with administrative and political domains although it is not an open space for public use. In this respect, the palace is significant by being both the upmost point and physical representative of political formation. Therefore, any physical or spatial interventions made to the palace reflect the interventions applied in other social places of city. It is important to examine the palace in a socio-temporal perspective in evaluating the symbolic meaning it has been holding and its place in the collective memory.

Politics has been the Ankara's core business, that is, the illustration of the power is predominant in the cityscape. Affected from the change in the political structure, Ankara has not been only the capital of a country, but also the symbol of a new identity construction as being both the producer and product of social and spatial transformation. Beginning from the 1990s as the decade of a stark differentiation, the rift in society polarized in the early 2000 s in Turkey. Despite the opposition parties and public reactions, the passionate government of 2000s imposed its political control over the space and symbols of previous era. The new political hegemony supported by the majority of the society differentiated themselves from "others" through creating a new state approach and changing the national past.

The presidential palace is used in this study to examine the change in the distinctive symbolic and aesthetic significance to denote the political power. The research depends on the thesis that the production of the symbolic icon is driven by those who controlled the state to transmit its political approach to the public. The argument is illustrated with respect to debates around the politics of monumentality in spatial planning, the relationship between symbolic spaces and political power, and a critical presentation of how these spaces are perceived by public.

This paper argues that government buildings as well as presidential palaces represent the symbols of the political regime. At the intersection of urban space and politics, Henri Lefebvre and following literature stress that space is the product of social conditions. This paper attempts to carry the argument a step further by digging the question that how political power is embedded in the spatial organization and design of presidential palaces. Symbolic state buildings are to be evaluated with respect to political contexts. The presidential palaces serves as an interesting subject in determining this relation, as the palaces are the expressions of the political manifestation together with their locations in the capital cities. A change in the political context may have influences on the symbolic message of the authority, its political and iconographic space, and consequently on the collective memory and the urban characteristic. The argument raised in this paper shed light on the discussion of the fragmentation in symbolic meanings of iconographic spaces with respect to political restructuring which could present a basis for further discussion in other capital cities having fluctuations or vulnerabilities in political contexts. 


\section{The core of power: Ankara in the early republican era}

Following the War of Independence (1919-22), the new Turkish Republic was established on October 29, 1923. In the subsequent years, Kemalist revolution was launched in social, economic, and political aspects to constitute the foundational ideology of the Turkish state. Turkey has been a unitary state model that was constructed upon the core values of national sovereignty and modernity.

Denying the agglomeration economies around Istanbul as a centre of development (Keskinok 2010: 176), the state aimed at implementing even development among regions by nationalization policies. As a result of economic goals targeting the regional integration of national territory and the ideological goals leaving the former regime's heritage in addition to the security problems of Istanbul constituting a threat on the new regime, the leaders of new government decided to move the capital. To this end, on October 13, 1923 Ankara replaced Istanbul as the capital of Turkey, shortly before the declaration of Republic. The economic, politic and spatial strategy of the new state in behalf of Ankara associated with the nation-state construction ideals. Ankara's geographical location away from the Ottoman capital, and lack of political and historical significance in the Ottoman and Islamic past served as a "metaphorical distance that the new state wanted to take from the imperial and Islamic frame of the Ottoman Empire" (Cinar 2014: 228). In creating the future of a nation, the new regime chose its past - "largely seeking a divorce from the Ottoman influences in favour of Hittite symbols and subtler Greco-Roman references to achieve a pre-determined future of civilizational accomplishments and greatness" (Glyptis 2008: 355). In addition to the very first movement, the state proclaimed republic as the new government model, applied nationalization policies in economic terms, constructed new state factories and integrated railways, liberalized rural labour, prepared comprehensive development plans, and undertook social reforms.

Parallel to the economic rationalism and social transformation movements, the city planning efforts took place in the early 1930s. Keskinok argues that "in this period, city planning is based on the creation and development of the public spaces in an environment that was to be shaped with the modern life style of the idealized Republican Citizen" (2010: 184). The new regime aimed at developing a public realm in urban spaces to emphasize the modern social life practises. According to Cinar (2014), the image of the new nation benefitted from various mediums, including the writing of a new national history, establishing social and political institutions, and arranging cities and city spaces. In this sense, the government invested in the city planning activities by giving a particular priority to Ankara.

The making of the urban space of the capital city in accordance with an urban plan was a part of a comprehensive modern process of a nation-building program. In line with goal of identity construction for the new Turkish society, first citizens of Ankara would be the first Turks (Gur 2011). The capital idealized as a model for the Republican modernisation held a small population within the limits of the old city around the citadel. Ankara enabled the government a more appropriate space to construct the Republican symbols and new collective memory than Istanbul housing the cultural and political geography of the Ottomans.

Ankara which was regarded as an empty space to be built up as the space of the new regime despite its history rooted to Hittites. At the time of Turkish War of Independence, it was a town of 20,000 with a formidable citadel (Vale 2008). Rejecting the Ottoman and Islamic past, the new political order established the modern institutions of Republic, so that the new urban development was expected to site the major governmental buildings and public spaces for the capital city of the young ambitious nation with grand aspirations. Capital city planning has tended to be grand and comprehensive to create places "worthy of the nation". In doing so, the new state allocated a significant part of its scarce resources to the construction of Ankara. The urban affairs and architectural works were commissioned to foreign urban planners and architects. The very first initiative toward a development plan for Ankara dates back to 1923 and to the appointment of Carl Christoph Lorcher (Cengizkan 2004). Nevertheless, the Plan was partially rejected due to disagreements over design proposals concerning transformation of the old town around Ankara Castle since there was no possibility of successfully applying any plan in the old settlement because of the land speculation (Bademli 1985). However, the proposals regarding the new city were accepted which constituted the spatial basis of republic institutions, boulevards, squares, and the growing and urgent housing need of the population (Cengizkan 2004; Gunay 2006). Since Lorcher's plan was limited in size and scope to guide the construction phase, the need for the preparation of a general plan for Ankara was arisen (Kacar 2010: 46). In 1927, an international competition was organized to prepare an urban development plan for the city. Prof. Hermann Jansen who won the competition, would be the author of the plan enacted in 1932. Being less rigid and monumental than its alternatives, the main reason for accepting the Jansen 
Plan was its focus on the social context, the creation of green areas, the stress on the car age, industry and the workers district (Tankut 1993).

During the two decades after the War of Independence, the construction phase of the new capital was carried out. The capital of Republic was aimed to symbolize the futurist and revolutionary space for the new state. The plan was structured for the following 50 years around an estimated population of 300,000 . It aimed at regulating urban growth with respect to population increase. To ensure the development project, along with the statist approach 3 million $\mathrm{m}^{2}$ of land were expropriated by Law no. 583 in 1925 (Tankut 1993). Jansen's urban form was to surround Ankara Castle, focusing on pre-Ottoman history and developing a new city in accordance with the new regime (Kacar 2010). Many 20th-century plans have combined the baroque desire for the display of power with the City Beautiful desire for comprehensively coordinating cities around impressive centres (Abbott 2009). These cities have been laboratories and exhibit cases for modernist approaches to urban design. Similarly, in the Ankara Plan, a zoning approach was applied in order to differentiate urban functions geographically. In this way, administrative, residential, recreational, industrial, health and educational zones were created in the new city, distinct from the existing historical areas. Ataturk Boulevard was determined as the north-south axis of the city connecting the old and new towns. The boulevard, which constitutes the spine of the city, begins from the first national assembly beneath the citadel, crosses over the railway line, passes through the governmental district, and ends at the presidential palace in Cankaya.

Public spaces, ministries, city parks, institutions, and boulevards were consciously designed to constitute the modern symbols of the republic. Deriu's study picturing the capital with regards to European observers claims that "the emergence of Ankara to the international scene, in the early 1920s, should in fact be considered a re-emergence" through the modern architecture, public art and town planning (2013a: 498). The European visitors of Ankara found the city as "a capital in the desert" with its main avenue, wide sidewalks, gardens and pavements lit up by electrical lampposts, and modernist buildings discarded from any Orientalist imagery (Deriu 2013a; 2013b). Turhanoglu (2010) argues that the main feature of this period was that the state was not only symbolized by buildings, but also characterized by space. Urban design and architectural principles with strong ties to modernity were employed as the instruments for consolidating the new national structure. Jansen's plan envisioned the governmental centre to represent the landmarks of republican ideology and to display national prestige. Also, a new architectural approach was supported to generate the visual expression of the modernity and statist economic policies that were associated with the republican ideology.

The national style of late 1920s as a continuation of Ottoman neo-classicism in architecture became obsolete. At first, in the making of Ankara, Ottoman Revivalist style was born as a nationalist style and approved by the Republican elites. This period which is called as the National Architecture Renaissance or First National Style (Bozdogan 1980) was dominated by the Turkish Architects Vedat Tek and Kemalettin, and Italian architect Gulio Mongeri. In the early Republican years, the monumentality of new public buildings was obtained through such an approach that was characterized by symmetrical and axial mass design, pointed arches, tiles, wide eaves and decorated front facades (Batur 2005). The Ottoman Revivalist approach, Basa (2015: 3) identifies, as "an elite interpretation of stylistic features of classical Ottoman architecture, incorporating contemporary construction techniques and structural systems". Despite the paradox between reformist Republicans and Ottoman Revivalist style, the initial governmental and public buildings of Ankara were installed with obvious traditional features in this early construction period. In the late 1920s, in symbolizing the national character, the adoption of the traditional Ottoman forms and imperial ideals was highly criticized. Since the new regime aimed at a divorce from the İslamic and Ottoman past, the Republican intelligentsia advocated to erase the traditional traces in architecture, and consequently, to represent the new ideals through a modern urban fabric. There was an official and intellectual agreement on that the inclusive and radical modernity project could be achieved through progressive modernism in western world (Basa 2015). As reflection of this ideal in architecture, with the invitation of foreign architects the architectural approach gained an official-looking modernism. Bozdogan argues that "Modern architecture was imported as both a visible symbol and an effective instrument of this radical program to create a thoroughly westernized, modern, and secular new nation dissociated from the country's own Ottoman and Islamic past. [I]n this respect, architecture in the early republican Turkey can be looked at as a literally concrete manifestation of the high modernist vision" (2001: 6).

The production of space in accordance with the young Republican ideals and inspirations required a new architectural approach to denote the revolution in space. Especially after 1927, architecture was intentio- 
nally used as an instrument in order to build a new collective memory without any features of Ottoman and İslamic past. The imported modern architecture was to represent contemporariness of the new state to the world and sovereignty and modernity to the Turkish nation. The sense of homogenous nation associated with the emergence of the national architecture that "dictates a common style to be used in the new buildings, structures, and monuments across the country" in order to create an image of homogeneity, to nationalize space, and to reflect the identity (Cinar 2014: 240). Thus, the architecture of the public institutions was founded on functionality, utilitarianism and rationality in design by rejecting the imitation of traditional forms.

In conjunction with the statist and protective economic policies, the newly constructed buildings have both simple and modern traces in terms of their construction methods, materials and form. Their cubic forms, clear geometric shapes, simplicity of façades, large, simple and symmetrical masses presented the revolutionary ideas, homogeneity among citizens, and governmental authority (Kacar 2010; Ulug 2004; Bozdogan 2002; Aslanoglu 1980). The public buildings and their open spaces promoted harmony in proportions and scales to blend into the general silhouette of Ankara. Monumentality was observed in the symbols of War of Independence and revolutions. Bozdogan defines the architectural culture of early modernization period as "one big effort to reconcile the modern with the national" (2001: 7).

The government commissioned the architectural projects of the administrative center of the new capital to an Australian architect, Clemens Holzmeister who was "first invited to Ankara to construct Ministry of National Defense in 1927" (Basa 2015: 17). Holzmeister contributed to the construction period of Turkey by forming the buildings of Ministry of Public Works, National Defence, Interior Affairs, Supreme Court of Justice, and other official buildings such as General staff headquarters, Central Bank, Austrian embassy building, and above all else the Grand National Assembly. Tanyeli argues that along with the approach of Turkey for foreign expertise and labour, none of the architects were involved in as many construction activities as Holzmeister did (2010: 64). The reason behind the reputation and powerful influence of Holzmeister is related with the characteristics of his architecture.

In the later years of War of Independence, Mustafa Kemal resided in a room in the Agricultural School and then he settled down a stone house near the first railway station (Akcan 2012). During the construction period, a house, located in the vineyard region of Cankaya at the apex of the hill, was allocated to Mustafa Kemal on 30 May 1921 by the Ankara Municipality for residential purposes (Presidency of the Republic of Turkey 2015). The name of the hill would recall the Presidency and the site of power. During the period between 1921 to1932, this house was the witness of the War of Independence and the foundations of Republic until being restored as a museum. According to the Akcan's exhaustive study (2012), because of the modesty of the house, a Turkish architect, Vedat Tek, prepared a project for extension including an octagonal tower, a bay and a wing to the building which are still explicit.

Due to the inadequacy of the vineyard house despite the enlargement and renovation projects, construction of a new Presidential Residence came into the agenda which would convey the message of the new family model to the Turkish nation and foreigners. The projects of Fritz Hermann and Giulio Mongeri were rejected since the former project was found inappropriate due to its majestic scale and classical symbolist style and the latter was vetoed because of the use of Ottoman revivalist elements for the proposed building (Akcan 2010). Mustafa Kemal appointed with Holzmeister and asked for tearing down the old house. In the book "Clemens Holzmeister: An architect at the turn of an era", his own words are noted as "this house is the birthplace of the Republic you have founded. [F]or this reason it should never be torn down but be transformed into a museum. [W] e can build the presidential palace in another appropriate location" (Balamir 2013: 356). The architect took the role in designing a new President Residence in order to symbolize the state in international arena. The Presidential Palace, or so called Pink Villa (Pembe Kösk) was built up in 1932 and used as the residence of Ataturk till the end of his life (see Fig. 1). The new Presidential palace carried the symbolic essence of the pink house in Salonika in which Ataturk was born. The palace is not only the house of the President of a nation, but also the symbolic centre of an imagined and performed modernity.

In opposition to the splendid palaces of Ottoman sultans, the Villa symbolizing the national sovereignty and Western modernity was to be designed as an element to distinguish the Republican Turkey from Imperial Ottoman. Being one of the early Republican buildings, the Presidential palace was decided to be a powerful symbol of the regime having its roots on national sovereignty, secularism, and modernity. Thus, the house did not only give Ankara an expression of Republican capital, but also infused the cultural codes of Western life style. In order to erase the memories of war against Western countries and the Ottoman ruler's heritage on the nation, Bozdogan and Akcan 


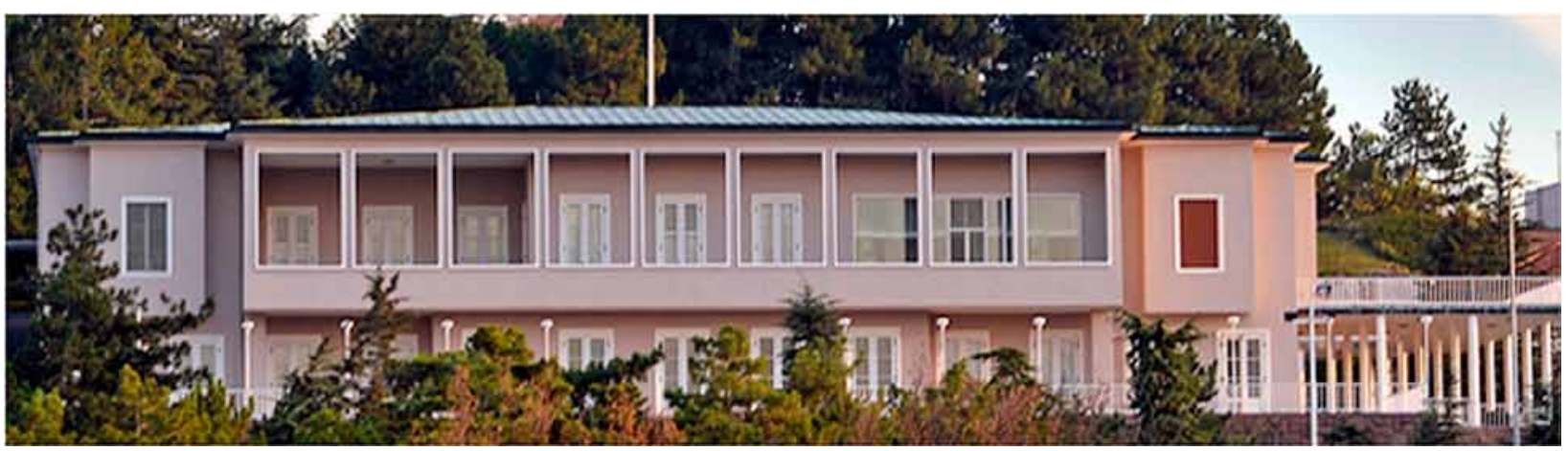

Fig. 1. Cankaya Palace of Kemalist period by Holzmeister (Presidency of Turkish Republic 2015)

claim that, Holzmeister used "modern monumentality in representing state authority with hidden layers of classism" (2012: 84).

The location of the Presidential residence had never been the focus of the city. The residence lies at the end of the urban spine, i.e. Ataturk Boulevard, far away from the central part of the city. As the Kemalist ideology supports the national sovereignty, the political space of the capital city was designed in the central part together with the republican institutions. In the Jansen plan, the southern hills of Ankara were reserved for the high income families' villas. Akcan (2012: 48) points in the book "Architecture in Translation" that "many of the houses for Ankara's new statesman were placed in this area, including Atatürk's Presidential Residence, for which Jansen used the German word "Schloss" (palace)". Although the Residence was situated away from the Ministries Quarter, the unity between them was prominently recognized. The modern expression of the new administrative units and Presidential residence reflected the contemporary design principles with respect to their geometric forms, symmetrical plans, and simplicity in their facades. Akcan writes down that "Holzmeister used common aesthetic motifs such as window proportions, accentuated lintels at the peripheries of windows, and projected boxes on the façade so that the Presidential Residence looked like a continuation of the Governmental Complex, the two together marking the unquestionable arrival of cubic architecture in the city" (2010:57).

The Pink Villa was to be a monument itself through the messages it conveys. This iconographic unit designated to contribute into national sovereignty by underlying the powerful effects of its simple silhouette and geometric design. It was designed according to the detailed specifications of Atatürk during 1930 and 1931. The symmetrical composed Residence reflects a transformation of traditional Turkish house having the main-floor raised on pilotis. Elevated on the columns, the Pink Villa was organized around an inner courtyard. The modernist style of the Residence was represented by its flat and pitched roofs, undecorated exterior walls, and symmetrical wings. The fringes of cantilever concealed the symmetry in the façade. The architect avoided spectacular façade elements apart from the natural characteristic and pattern of the material used for the building (Batur 2007). The interior space of U-shaped building was designed around an atrium and an arcade (Bozdogan, Akcan 2012). The house completely suited to the European style of living. Batur defines the House as Holzmeister's most modern building in Ankara and notes that "this beautiful work, which is very modest as a president's mansion, shapes a modernism acquired with the conversion of a classical diagram and design with classical motifs" (2005: 21).

Consciously intended to be the highest point of the new city, the siting of the Villa highlighted the power of the state symbolically, captured the imagination of modernity and national sovereignty, and commemorated the leading role of Ataturk over the nation. The visual condensation of the house in the eyes and minds of the people, Cankaya gained the most prestigious position in the city. It's very name recalls the highest position in the political hierarchy given by the national sovereignty. Taken together, the presidential palace is not only located at the apex of the administrative district of Ankara, but also at the symbolic apex of the republican Turkey. Gaining the most prestigious location in the city, politicians, ambassadors, high level bureaucrats, and media organizations sited gradually around the boulevard in Cankaya district.

The Pink Villa was used actively from 1932 to 1973 until becoming inadequate in meeting the administrative functions. With regards to the limited size of the Pink Villa, a new service building was decided to be constructed in the Cankaya Campus during the presidency period of Kenan Evren in 1986. The new presidential palace was designed by Aytore and Genc, and installed in the Cankaya campus in 1993. Constructed on a classical diagram with an obvious symmetry on 
the front façade, this new building gives reference to Holzmeister's design by its plain lines, pink colour, and the material (Batur 2006). Gradually, the residence of President showed a campus-like development with its offices, meeting rooms, and halls. The new main building together with the Pink Villa, Museum Villa, Glassed Villa, and Aid-de-camp's house constitutes the Cankaya Campus of Presidency. Thus, the symbolic meaning of Presidential Palace in Cankaya has expanded to become the place of republican regime for all country. None of the administrative functions removed from the area which provided large indoor and open spaces until the 2000s.

\section{The (de)politic dispersion: Ankara in 2000s}

The subsequent periods of Turkish Republic witnessed multidimensional changes in social, economic, and political structures, such as transition to multi-party regime, engaging in liberal economic model, and displaying populist policies. Since the 1950s, Ankara has begun to lose its ideological and symbolic burden. Especially in the 1980s, due to the reconciliation with its Ottoman and Islamic past, and the dominant neoliberal economic policies, Ankara was to experience a significant change, and even a trauma. This transition has been carried out step-by-step by destructing early Republican basis and building the roots of a new ideology. In this process, while Istanbul is gaining a central role for capital and global networks, Ankara remains solely as a political centre at national level in spite of being literally the ideological conveyor of such a significant message as a representative of nation.

The city has been restored by the capitalist movement of post-1980s. Incoming foreign investments, the pull of domestic market forces, and the new political power have redefined the capital city. Ankara and some other cities in Turkey have become post-industrial service cities, by economic evolution accelerated by privatization policies. Employment in service sector takes the front stage from the blue collar in industrial sector. The urban street, of consumers and flaneurs, has lost its importance against shopping malls including stores, restaurants, bars, and entertainment to all tastes. Individual transport has become a highly preferred option. The new landmark buildings are largely residences, business companies, and shopping malls constructed by private entities, although there are also others, like new mosques, institutions and public buildings handled by the public sector. Urban space is now governed primarily by money. Segregation is money-driven, the pattern of guarded, "gated communities" has spread across the city while the urban transformation projects increasingly lead to the social exclusion. As the principle of local autonomy has been established, the elected mayor has been able to put an important local stamp on the national capital. Since 1994, an enduring major has been governing Ankara and structuring the urban space whose political position can be regarded as an extension of the dominant right-wing policy.

The post-2000s is the period of contradictions; it is politically conservative and nationalist, economically neo-liberalist, and culturally increasingly cosmopolitan, but desirably homogenous. Nationalism in Kemalist terms was never an attractive idea for the new period, rather the new state aimed at building a distinct national structure with historical and religious references. Political monumentality and ideological dominancy are nationalist, with a recent break from Europeanness, or Western modernity. At the same time, there is an economic break from the national investments. The popular nationalism was observed everywhere despite the recent revolt of civil society against the absolute power of the central government.

As part of the contemporary political context, the urban scheme of the capital has been reproduced (Batuman 2013a, 2013b, 2014; Bozdogan, Akcan 2012). Urban politics of post-2000s Turkey are designed under the conditions of neo-liberal urban regime coupled by Islamic cultural politics. Batuman writes that "the Islamists" rise to power in Turkey in the past two decades started at the level of local administrations" that strengthened their hegemony with a populist welfare system utilizing Islamic social networks (2013b: 1099). Benefiting from the religious network in capital accumulation and distribution, and embracing democratization against the constant militaristic threat, the Justice and Development Party has gained a wide support of the nation. With respect to neo-liberal economic approach of the ruling party, the urban space is regarded as a significant means of capital accumulation (Batuman 2013a, 2013b). Urban regeneration projects came into agenda to represent Islamic symbolism and conservative daily practices on space and to commodify the space by slum upgrading and building luxury housing. In spatial terms, suburbanization and decentralization is entering the city, while the inner cities are thinned out by the expansion of office space. Bozdogan and Akcan illustrates the policies of this period as "opening new land to construction, selling public land in prime urban locations to private real estate development companies to generate revenue, relaxing codes on taller buildings and changing zoning codes, transforming traditionally residential areas into commercial zones" in forms of consumption spaces such as malls, international hotels, theme parks, retail 
and fast-food chains, and office and residential towers (2012: 205). Additionally, the political scene dominated by the ruling party makes emphasis on the Islamism as a political ideology, and the urban symbols of this period reflects a new understanding of nationalism compatible with Islamism. Many of the early Republican restrictions on religious expression gave way to a populist and conservative discourse in favour of Islamic and Ottoman heritage. This conservative shift affected the political and cultural context as well as the physical environment and the symbols of the society. A new national urban pattern has not settled yet. But a couple of tendencies are discernible. A general outcome of the architectural concerns is arousing the pre-modern imperiallinks. Thus, Ankara, together with other Turkish cities witnessed the praising of Ottoman revivalism in the urban environment.

The revenge has been visible on the Republican space; the spaces of interventions were selected deliberately by the new political power came in force in the 2002 central government elections. In this period, buildings identified with Kemalism have been abandoned intentionally. Despite to be assigned new functions, these buildings have been isolated from the urban life not in physical terms but in symbolic meanings by breaking its ties with city. Unsurprisingly, there have been those who ignore or challenge Ataturk's legacy and the potency of the images. However, none of them have attempted to alter the topmost address of Turkish Republic.

Along with the all destruction processes realized in Ankara, the Presidential Palace took its toll from the ideological transformation. The victim of the struggle of ideological supremacy on space is the Ataturk Forestry Farm (or Ghazi Farm). The Farm was founded by Mustafa Kemal to be "a pioneering enterprise for agricultural transformation by using scientific methods and modern technology" (Keskinok 2010: 177). In line with goals of the urban-rural integration and liberation of rural labour, the purpose of the state farm was enhancing productivity by mechanization in agriculture, using innovative agricultural techniques, educating agricultural work, developing agricultural industry, supporting it through cooperatives, and building a modern sample of living environment for workers. The farm was built deliberately on a non-fertile land of Ankara. This selection had ideological roots, as mentioned by Mustafa Kemal (1925) "if we do not improve this land, then who will come to do it?". Established on May 05, 1925, by his individual efforts, the Farm has been one of the concrete achievements and become symbol of the republican regime. The modernization story of the Turkey was written on the Farm: the marsh was rehabilitated and forested; science, positivist techniques and technology was used for agricultural production; research and development was supported; agricultural factories was constructed to provide healthy and delicious food to citizens; accommodation facilities, a primary school, a public bath, a station, a post office, and administrative units were built to meet the daily life requirements of employees; social life practises was generated in public spaces through pools, gardens, restaurants, and weekend hotels (see Fig. 2). The Farm was designed by a Swiss architect, Ernst A. Egli, together with the German planner of Ankara, Hermann Jansen. Egli's plan had been "a small model of the national modernity project, with the social, cultural and historic implications it has" (Alpagut 2010: 263). Establishing the pioneering enterprise, Ataturk donated the Farm to treasury and to Turkish nation. Being a modern role model for other state farms, Ghazi Farm provided a comprehensive schema by its contribution on economy, social life and republican symbols.

In the following years of the construction period of Ankara, the territory of the Farm has become to decrease

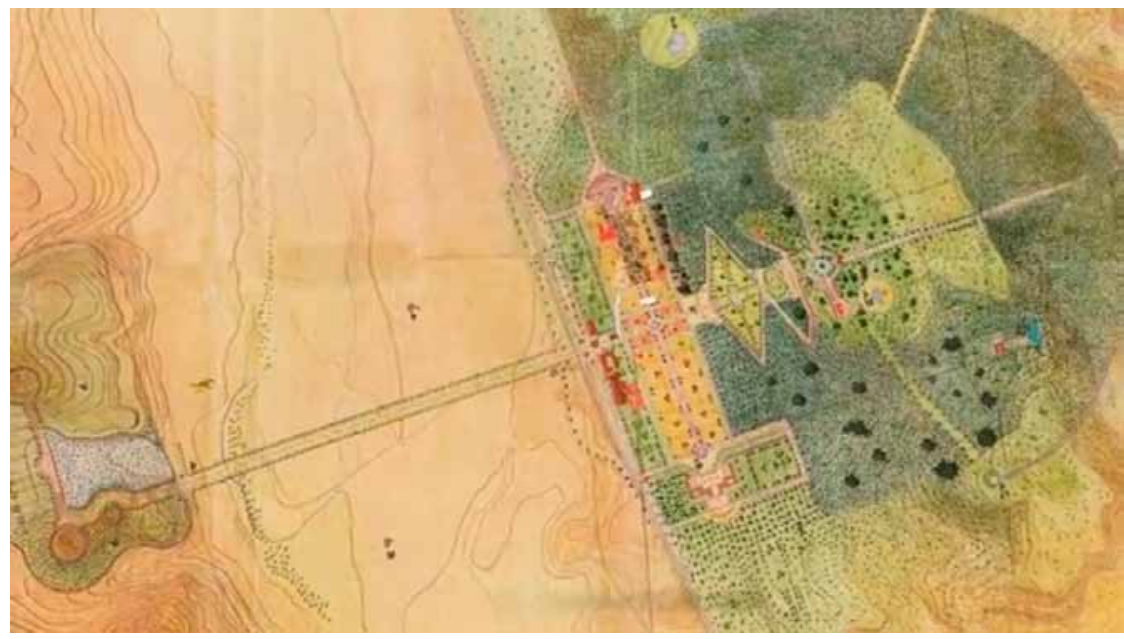

Fig. 2. The plan of Egli for Forest Farm (AOÇ Araştırmaları 2014) 


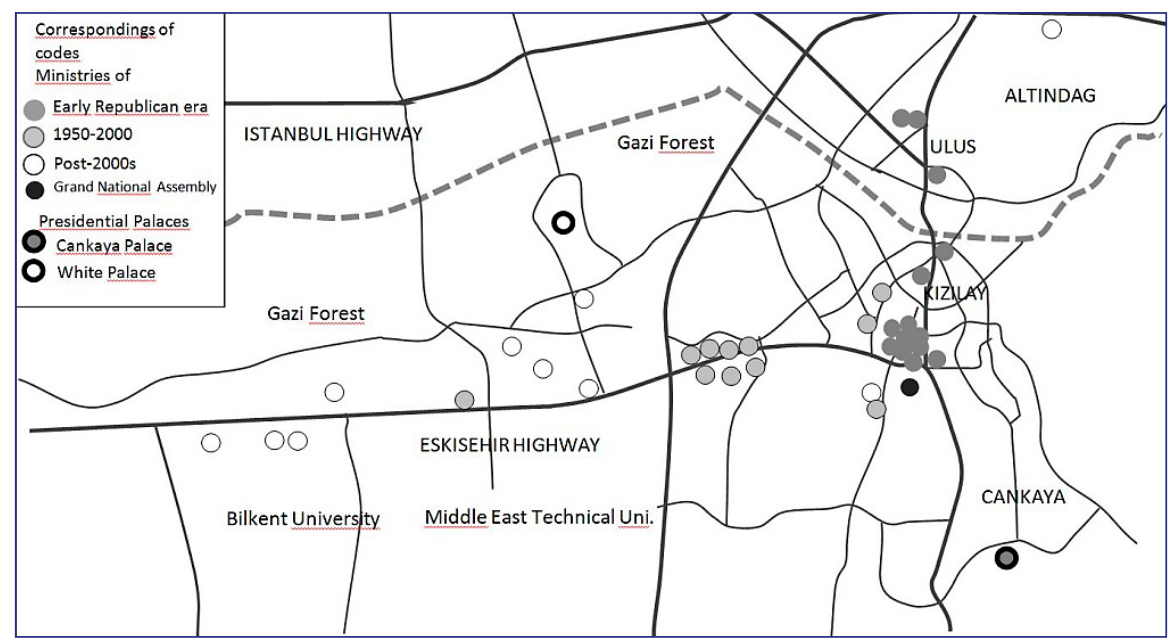

Fig. 3. Present locations of ministries and presidential palaces in Ankara according to their construction periods

by allocating land to the use of private sector and public institutions. Especially, in the post-2000s, the Farm was subjected to an intentional intervention at state level. Since the comprehensive urban plans sat on the shelf after the 1980s, the local and central governments of Ankara prepared several planning schemas for the Farm territory. The Farm area is seen as vacant land suitable for exploitation and the vacant land has been gradually and partially allocated to use of public and private entities without respecting to its original and principle function. The site selection for new Presidential Palace is also an outcome of such a piecemeal planning approach. Therefore, under the circumstances of uncertain land-use decisions and authoritarian state power, the Palace would be settled in the middle of the Forest Farm (see Fig. 3).

The White-Place ${ }^{1}$ was constructed for Erdogan ${ }^{2}$ by being the most assertive place among the other public

\footnotetext{
1 The Turkish abbreviations of the Justice and Development Party is AKP, yet is widely used as AK Party. In Turkish, the synonym of ak is white. Elaborating on the White House in USA and continuing discussions on presidency system, the AKP officials called the new Presidency as Ak-Saray (White Palace). During the construction, Erdogan selected as the President of Turkish Republic and the building was allocated to Presidency. Opponents claim that the building was constructed for Erdogan himself whatever his position is prime minister or president Following the court decisions which declared the illegal land allocation for the Palace from the Forest Farm, opponents began to call it as Kaç-Ak Saray (Squatter Palace). Due to the very popular and antagonist connotation, AKP officials quickly abandoned the naming $A k$-Saray, and the emphasis on the name of the district (Bestepe) came to the foreground which was registered as a trademark by the Presidency on October 2015. Erdogan also made another radical change and declared the name of Presidency as Külliye (the complex of buildings adjacent to a mosque) referring to Ottoman past and Islamic ties. The new name of the Palace as Cumhurbaşkanliğı Külliyesi was declared officially on July 7, 2015.

2 Justice and Development Party came in force in 2002 central government elections and Recep Tayyip Erdogan has been the Prime Minister of Turkey until 2014, by gaining the majority of votes. During the years of single party government, Erdogan was selected as the President in 2014. The building in the Gazi Farm was initially designed as the Prime Ministry Office, but after the Presidential Elections, the office was shifted to the Presidential Palace.
}

institutions. The power of the new authoritarian state figure comes from the support of the majority of nation which is used instrumentally, especially in the violation of court decisions. Located on the first degree naturally and culturally protected area, the presidential power obtained so-called from the national willpower provides itself a transcendental authority and privilege by settling the Palace in the Farm area.

The project process of the Palace was not transparent. Even, the construction period of buildings was kept apart from the media and public until it was completed. During the construction, the judiciary process has continued. Despite the judgments that announces the illegal land allocation from the Forestry Farm, and that declares to stay of order, together with the Erdogan's rigorous statements, the Palace was constructed.

The most assertive architectural attempt of post2000s period would be the new Presidential Palace ${ }^{3}$. The campus of the Palace includes official blocks, a residential block, and a mosque apart from a series of service buildings. The symmetrical official buildings are located around a rectangular courtyard. The presidential office block sits along the main entrance and has a panoramic city view due to its hilarious location in the Forestry Farm. The square in front of the Palace illustrates a public space, which cannot be a representative of a democratic public space because of its subordinating location between the house of the authority, the office of execution and the holy place of a religion.

The monumentality in presidential palace is an attempt to affirm and display the symbol of the new politics. The White Palace, and the controversy

3 The Presidential Seal was moved to the White Palace on January 29,2015 that denotes the official end of an era of Kemalist state tradition. 
surrounding it, clearly stem from a wider political project that includes the ruling party's contentious plans for constitutional reform, with significant changes to the President's role. The luxuriantly decorated building with its crushing grand mass serves to stimulate the power and privilege (see Fig. 4). The symmetrical building on a landscaped high ground makes the sense of a consciously created symbolic space over the public. However, current public access to the Palace is thoroughly discouraged. The hilltop with its huge neoOttoman structure is a place that evokes a picture of what the power of an Ottoman Sultan was like in the 18 th century.

The Palace was designed by a Turkish architect, Şefik Birkiye who undertook several international and national projects. 18th century Ottoman-Islamic architecture was embraced in architectural terms. The new Presidential Residence, like its early Republican ancestor, was a part of governmental cultural programme; yet the main difference occurs in the symbolic focus. The new Residence reflects the divergence from the radical secularism and westernization goals of Kemalist ideology. The Ottoman Revivalist approach, "declined over time due to the new (and political) comprehension of space as something more than the outcome of professional design" (Basa 2015: 20), seems to be intentionally installed to the Presidency in line with current sociocultural and political context. Basa (2005) summarizes the tide of Ottoman Revivalist experience during the early Republican period as "from praise to condemnation". In the post-2000s political environment, it could be seen that greater privilege and prestige is again given to Revivalism. This building is an intervention to the gradual decline of Revivalism in 1930s in line with the ambition of young Republic to construct a collective memory not including the Ottoman and İslamic past. By this way, the political authority reflects its power over space and used Revivalism as the expression of the decline of the modern symbols and images assembled to the Republican ideology.

The architectural language of the Palace is consisted of wide roof trees, column series, and Ottoman and Seljukian adornments in order to compose the Revivalist approach. The building has a symmetrical and axial mass design. Each façade of the Palace displays its rules of composition with columns, windows and doors. In order to emphasize the vertical elements of the composition, double and triple column groups are used in the facade. The rates and proportions of the space and mass also contribute to the strict symmetric design of the building. The monolithic structure of the block is divided by the multiple ceiling covers.

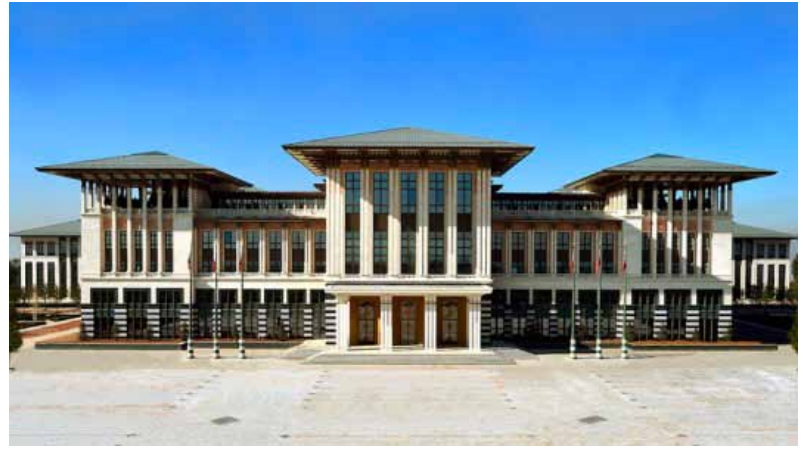

Fig. 4. White Palace of post-2000s period, by Birkiye (Arkitera 2015)

The partial façade composition highlights the sense of deepness, by this way the building breaks the simplicity of its diagram. The design of the building intentionally disregards the use of arches and walls to lighten its mass. Also, the colour of first floor is differentiated from the rest of the building for the same reason. The Inside, the Palace includes a thousand rooms decorated with high technology and expensive equipment. Thus, it is fair to claim that the (post-modern) Revivalist design supports the prestige and magnificence of the new presidential house rather than meeting the functional essentials.

The Palace has been highly criticised through academicians, non-governmental organizations and chambers, media, and opponent politicians in Turkey since the very beginning of the land allocation to the Palace. Most of the criticisms are related to the illegality of its location choice which takes place on news nearly on everyday basis due to continuation of judiciary process. Also, the neoclassic architectural images of the Palace and its huge budget draw oppositions. Ottoman revivalism based architectural approach has been used as the national architectural style to illustrate the political image and power over the society. Since there is not any intersection point between these historical periods, the invented SeljukianOttoman style does not actually make sense in the discipline of architecture (Batuman 2014). Rather, this apocryphal style does only imitate the golden ages of these previous states. Today, the reference made to the most powerful periods of the empires is used intentionally to denote the hegemony of the official ideology of the state and to be differentiated from the early Republican modernism visually. Besides, international media released news about the Erdogan's palace by emphasizing the glory of the buildings, their numerous rooms and the luxury interior designs, and the expenditures made for the Palace. 


\section{Conclusions}

Space is composed of a physical environment and an abstract meaning in which the meaning requires to be evaluated as a cultural entry. The urban symbols and historical meaning shaped by practises helps the development of collective behaviour and the formation of the social characteristic. The urban space is the stage of the production, continuity and transfer of urban memory to future. Breaking the continuity of spatial meanings and assigning new roles to them lead to weakening of symbols in collective memory and consequently disappearing in time. The multi-layered urban forms are the indicators of cultural prosperity. The urban characteristic is likely to be demolished unless the traces of layers are protected and newly produced one is integrated to the old layer. In this respect, the ruling power determines the identity construction by making decision on those having enrolled today through recalling the collective memory.

The Jansen Plan is the most significant document in Ankara's planning history in understanding the approach of the young republic to a modern city. The plan guided the urban development and the rapid transformation of a small and poor town into a nation's capital. Since the 1950 s, the years of migration and urbanization, a series of plans were prepared to enhance the initial efforts. However, especially after the 2000s when neo-liberal policies became dominant over space and when comprehensive planning lost its prevailing position against political intents, the city was to be formed by piecemeal attempts. Public places and buildings lost their primary focus and their symbolic meanings. A new political landscape was shaped on a formerly identified territory of early Republican period.

Looking back to this period from today, the modernity project of Turkey incorporating the social, political, economic, physical and spatial attempts can be identified as a successful project despite the deficiencies in monetary, legal and technical conditions and despite its top-down approach. However, from the 1950s, the urban fabric of Ankara was transformed far more than it had been by the early republican interventions. The urban development of Ankara began to differ from what was initially intended. Due to the population growth through urban migration, illegal squatter areas emerged around the proposed limits of the city. Together with the speculative demands of wealthy citizens, urbanization from north to south could not be controlled. Though the main lines of the modern capital of Turkey were drawn by these early interventions, Ankara, with its over 4 million residents, has a more complex urban structure today.
Through a comparative discussion of urban symbols of state sovereignty in Turkey, this paper examined the change in meanings and spatial organizations of presidential palaces. The presidential palace produced in the early Republican period differs from the one produced in the global era of Turkey not only in terms of form, but crucially in terms of the meaning that represent the political and economic approaches of each periods. In Gordon's terms (2004), Ankara's former Presidential Palace is the product of a nationmaking, capital-making, and city-making process. It is the site of the powerful symbol of national sovereignty and secularity. Divergence of the conservative ideology of post-2000s from the republican ideology has been creating new spaces, and demolishing collective memory and urban identity. The new political power aimed at developing its own symbolic spaces. In this respect, being the most significant and upmost building pertaining to the political system, it is right to claim that the address of Presidential house was deliberately changed.

The presidential palaces examined here illustrate key conclusions regarding in which ways the construction principles of the authorities were instituted through the arrangement of the urban space, designing its architectural concerns, and conveying a message to both the citizens and the nation.

In terms of spatial organization of the city, the former presidential house in Cankaya, Pink Villa, has never been the focus of the city although it has a panoramic city view due to its location over the hill. Rather, the Presidential Villa was designed at the end of the original urban spine. In that time, the centre of the city has been the site welcoming the newly established buildings of the execution and the legislation. In spite of the first spatial organization of the city and political order, the new period shifted the central point of the city in parallel to the spatial enlargement. Today, the new address of the President would be the new centre of city that has already sprawled along the western corridors. By the short transmigration of the President, the sequence of the political powers in the parliamentary system would be changed. In the new ideology, the apex of the politics seems the President rather than the National Assembly.

The shift is seen not only in spatial arrangement of the city, but also in the architectural representation of the power. The ultimate change can be read in the scales of Presidential Villa and the Palace. Despite the modest and modern design of the Pink Villa, the White-Palace draws attention with its Ottoman revivalist architectural image, grand size, and expensive decorations. The Presidential house is required to consolidate with the general structure of its society 
and surrounding spaces in order to be identified with the city, in specific, and the country, in general. It is obvious that having Islamic and Ottoman traces, the Palace does not correspond to the spatial pattern of Ankara, the Republican ideology, the average income level, and the national sovereignty ideals. The imperial Ottoman symbols and the Seljukian pattern, forms and styles deliberately selected from the past in parallel to the ideology of the new authority are resulted in degradation, artificiality, and kitsch. Despite the expenditures and revivalist efforts, the Palace with its monumental mass may only evoke the ashes of an imitated history.

However, comparing the Palace solely with its ancestor is not enough since the splendid size and uncommon cost of the building affects the whole parliamentary system. The Parliament that represents the whole nation lost its privileged position across the executive power in terms of architectural image. Obviously, the Palace conveys the symbolic message of the power of the President to public by shading any other public institutions in the city.

In addition to the loss of the symbolic meaning of Cankaya and political focus, Ataturk Forestry Farm is subjected to a change in meaning. The Farm that illustrates the ambitions of a young nation for being a developed and a modern country has been regarded as an empty basis for the construction intentions of the new ideology. The testament of Ataturk for Farm was disobeyed, and the collective memory was erased. The Farm was physically demolished, and a wide extent of its territory was allocated despite the opposing court decisions. The public access to the Palace was prohibited; therefore, the publicly owned land which was bequeathed from Ataturk to Turkish nation was occupied illegally.

By discussing the formation and reproduction of presidential palaces as a deliberate project of political intents, this paper concludes that the transformation of urban symbols to demonstrate the prevailing power supposedly changes the notion of national meanings. Underlying power struggles, tensions, and conflicts seek a divorce from constructed symbols and references, and create its influence to achieve new official symbols. If the societal and national structure remains reckless to these changes, the new authority can easily find itself a new place and new form to be constructed. Such destructive processes are supposed to be taken into consideration, and a communication milieu is to be generated to mediate for memory construction and to maintain the continuity of urban identity.

\section{References}

Abbott, C. 2009. Book review: planning twentieth century capital cities, in D. L. A. Gordon (Ed.), Journal of Urban Design 14(3): 402-404. http://dx.doi.org/10.1080/13574800903056911

Akcan, E. 2012. Architecture in translation: Germany, Turkey and the modern house. Durham, New Castle: Duke University Press.

Alpagut, L, 2010. Traces of Ernest Egli in Ataturk Forest Farm: Site planning, beer factory, housing and the traditional hamam, METU Journal of Faculty of Architecture 27(2): 239-264. http://dx.doi.org/10.4305/METU.JFA.2010.2.13

Arkitera. 2015. White Palace [online], [cited 14 May 2015]. Available from Internet: http://www.arkitera.com/gorus/829/ak-sarayin-mimari

AOÇ Araştırmaları. 2014. Egli Plan for Ataturk Forest Farm [online], [cited 14 April 2015]. Available from Internet: http://aocarastirmalari.arch.metu.edu.tr/aocde-bir-gezinti-egli-3d/

Aslanoglu, I. 2001. Erken Cumhuriyet Dönemi Mimarlığı 19231938. Ankara: METU Faculty of Architecture Publications.:

Bademli, R. 1985. 1920-1940 Döneminde Eski Ankara’nın Yazgısını Etkileyen Tutumlar, Mimarlık 23: 212-213.

Balamir, A. 2010. Clemens Holzmeister: an architect at the turn of an era. Ankara: Boyut Collection.

Basa, I. 2015. From Praise to condemnation: Ottoman Revivalism and the production of space in early Republican Ankara, Journal of Urban History 41(4): 711-738. http://dx.doi.org/10.1177/0096144214566957

Batuman, B. 2013a. City profile: Ankara, Cities 31: 578-590. http://dx.doi.org/10.1016/j.cities.2012.05.016

Batuman, B. 2013b. Minarets without mosques: limits to the urban politics of Neo-liberal Islamism, Urban Studies 50(6): 1097-1113. http://dx.doi.org/10.1177/0042098012464402

Batuman, B. 2014. Okul cephelerinden Cumhurbaşkanlığ Sarayına: Mimari Temsil olarak Osmanlı-Selçuklu ve Ulusun Millet olarak (Yeniden) İnşası, Arredamento Mimarlik 285(12): 65-73.

Batur, A. 2005. A concise history: Architecture in Turkey during the $20^{\text {th }}$ century. İstanbul: Chamber of Architects of Turkey, Cizgi Press.

Belanger, A. 2002. Urban space and collective memory: Analysing the various dimensions of the production of memory, Canadian Journal of Urban Research 11: 69-83.

Bozdogan, S. 2002. Modernism and nation building: Turkish architectural culture in the Early Republic. Seattle: University of Washington Press.

Bozdogan, S.; Akcan, E. 2012. Turkey: modern architecture in history. London: Reaktion Books.

Campbell, S. 2000. The changing role and identity of capital cities in the global era, in Association of American Geographers Annual Meeting, April 2000, Pittsburgh.

Cengizkan, A. 2004. First plan of Ankara: 1924-25 Lorcher Plan. Ankara: Arkadas Press.

Cinar, A. 2014. State building as an urban experience, in M. Minkenberg (Ed.). Power and architecture: the construction of capitals and the politics of space. New York: Berghahn books.

Curtis, W. 1996. Modern Architecture since 1900. 3rd ed. London: Phaidon. 
Deriu, D. 2013a. Picturing modern Ankara: New Turkey in Western imagination, The Journal of Architecture 18(4): 497-527. http://dx.doi.org/10.1080/13602365.2013.822014

Deriu, D. 2013b. A challenge to the West: British views of Republican Ankara, in M. Gharipour, N. Ozlu (Eds.). The city in the Muslim world: depictions by Western travel writers. Routledge.

Ergut, T. E. 1999. Making a national architecture: architecture and the nation-state in Early Republican Turkey. Michigan: UMI, A Bell \& Howell Company.

Evered, K. T. 2008. Symbolizing a modern Anatolia: Ankara as capital in Turkey's Early Republican landscape, Comparative Studies of South Asia, Africa and the Middle East 28(2): 326341. http://dx.doi.org/10.1215/1089201x-2008-009

Glyptis, L. 2008. Living up to the father: The national identity prescriptions of remembering Atatürk; his homes, his grave, his temple, National Identities 10(4): 353-372. http://dx.doi.org/10.1080/14608940802271647

Gordon, D. L. A.; Osborne, B. S. 2004. Constructing national identity in Canada's capital, 1900-2000: Confederation Square and the National War Memorial, Journal of Historical Geography 30: 618-642. http://dx.doi.org/10.1016/S0305-7488(03)00041-0

Gunay, B. 2006, Ankara cekirdek alanının oluşumu ve 1990 nazım planı hakkında bir degerlendirme, in T. Senyapılı (Eds.). Cumhuriyet'in Ankara'sı. Ankara: METU Press.

Gur, B. 2011. Unutmak, öteki ve boş kent Ankara, İdeal kent: Kent Araştırmaları Dergisi 4: 8-20.

Halbwachs, M. 1992. On collective memory. Chicago, IL: University of Chicago Press.

Holod, R.; Evin, A.; Ozkan, S. 2007. Modern Turk Mimarligi 1900-1980. Ankara: Chamber of Architects of Turkey, Yalcin Press.

Hutton, P. 1993. History as an art of memory. Hanover, NH: University Press of New England.

Kacar, D. 2010. Ankara, a small town, transformed to a nation's capital, Journal of Planning History 9(1): 43-65. http://dx.doi.org/10.1177/1538513209359869

Keskinok, H. C. 2010. Urban planning experience of Turkey in the 1930s, METU Journal of Faculty of Architecture 27(2): 173-188. http://dx.doi.org/10.4305/METU.JFA.2010.2.9

Minkenberg, M. 2014. Power and architecture: the construction of capitals and the politics of space. New York: Berghahn books.

Mitchell, K. 2013. Monuments, memorials, and the politics of memory, Urban Geography 24(5): 442-459. http://dx.doi.org/10.2747/0272-3638.24.5.442
Osborne, B. S. 1998. Constructing the landscapes of power: the George Etienne Cartier monument, Montreal, Journal of Historical Geography 24(4): 431-458. http://dx.doi.org/10.1006/jhge.1998.0090

Presidency of the Republic of Turkey. 2015. Cankaya Campus and Museum Villa, Palace [online], [cited 14 April 2015]. Available from Internet: http://cankaya.gov.tr/sayfa/ cumhurbaskanligi/yerleskeler/

Shatkin, G. 2005. Colonial capital, modernist capital, global capital: the changing political symbolism of urban space in metro Manila, the Philippines, Pacific Affairs 78(4): 577-600. http://dx.doi.org/10.5509/2005784577

Tankut, G. 1993. Bir başkentin imarı. İstanbul: Anahtar Kitaplar.

Tanyeli, U. 2010. Holzmeister and the "tamed' modernism of the early republican Turkey, in A. Balamir (Ed.) Clemens Holzmeister: an architect at the turn of an era. Ankara: Boyut Collection.

Therborn, G. 2006. Eastern drama: capitals of Eastern Europe, 1830s-2006: an introductory overview, International Review of Sociology - Revue Internationale de Sociologie 16(2): 209242. http://dx.doi.org/10.1080/03906700600708816

Therborn, G. 2010. Monumental Europe: the national years. On the iconography of European Capital Cities, Housing, Theory and Society 19: 26-47. http://dx.doi.org/10.1080/140360902317417976

Therborn, G. 2015. City and power, International Journal of Urban Sciences 19(1): 1-6. http://dx.doi.org/10.1080/12265934.2015.969416

Turhanoglu, F. A. 2010. Spatial production of Ankara as Capital City of Republican Turkey, The International Journal of Interdisciplinary Social Sciences 5(5): 309-318. http://dx.doi.org/10.18848/1833-1882/CGP/v05i05/51734

Ulug, H. 2004. Yeni Baskentler, Tasarım ve Siyasi Iktidar, Planlama 1: 39-57.

Vale, L. 2008. Architecture, power and national identity. $2^{\text {nd }} \mathrm{ed}$. New York: Routledge.

\section{EZGI ORHAN}

She is Dr, Conducted her PhD research at Middle East Technical University, Turkey, in 2012. The author has been working in Cankaya University in Ankara, Turkey as an assistant professor. She published several articles on post-disaster recovery, businesses and disaster planning. Her main research interests are business geography, planning theory, and spatial organizations. 